\title{
Problemy z narracją. Kilka uwag po lekturze Davida Parkera
}

\author{
Narrative Issues: Post-Reading Notes on David Parker
}

Abstract: The present article constitutes an extended three-part commentary to the chapter Life Narrative and Languages of the Good from the book The Self in Moral Space: Life Narrative and the Good by David Parker. The first part of the paper is a critical discussion of the views espoused both by Parker and by Charles Taylor, whom Parker cites in his work. On the one hand, the author agrees that acquiring a sense of identity is practically impossible without a horizon of values which gives origin to our identity. On the other hand, he rejects the premises underlying this conclusion, primarily the assumption of a necessary iunctim between ethical consciousness and ethical acts and the literary-textual matrix of comprehending humans and the world. In the second part of the article, the author puts forward his own interpretation of the book Roland Barthes par Roland Barthes, independent from the one proposed by Parker, discussing it as an example of practicing identity in the form of a literary-typographical-visual performance. The third part of the paper seeks to open a broader discussion of narrativist concepts by indicating six issues connected with their application: the privileged position of cognitive processes in experiencing the world and one's self; the perception of the world and humans through the lens of the textual model; the methodological principle of studying narrative textual products and not practices bringing them to life; the conceptualization of a textual subject as a lonely subject, isolated from the network of social relations; the universalization of the subject of narrative operations, lack of diversification of narrative practices by gender/sex and social class/group; the semiotic conceptualization of mundanity as an element of narrative identity.

Keywords: narrative, narrativism, identity, text, literary practice, mundanity, Barthes Roland, Parker David, Taylor Charles

Streszczenie: Artykuł stanowi rozbudowany, trzyczęściowy komentarz do rozdziału z książki Davida Parkera The Self in Moral Space: Life Narrative and the Good, zatytułowanego Narracja autobiograficzna i języki dobra. W pierwszej części autor dyskutuje z poglądami Parkera oraz Charlesa Taylora, na którego Parker się powołuje. Z jednej strony zgadza się z nimi, że poczucie tożsamości jest zasadniczo niemożliwe bez horyzontu wartości, który naszą tożsamość czyni możliwą. Z drugiej strony odrzuca przesłanki tego stanowiska, przede wszystkim założenie koniecznego iunctim między świadomością etyczną a postępowaniem etycznym oraz piśmienno-tekstową matrycę rozumienia człowieka i świata. W kolejnej 
części autor proponuje własną, odmienną od ujęcia Parkera, interpretację książki Roland Barthes par Roland Barthes jako przykład praktykowania tożsamości w postaci piśmienno-typograficzno-wizualnego performansu. Część trzecia artykułu to próba podjęcia bardziej ogólnej dyskusji z koncepcjami narratywistycznymi przez wskazanie kolejnych sześciu problemów jako składników tych koncepcji: uprzywilejowanie procesów poznawczych w doświadczaniu świata i doświadczaniu samego siebie; postrzeganie świata i człowieka poprzez model tekstowy; metodologiczne założenie badania narracyjnych wytworów tekstowych, a nie praktyk powołujących je do życia; ujęcie podmiotu tekstowego jako podmiotu samotnego, wyizolowanego z sieci relacji społecznych; uniwersalizacja podmiotu operacji narracyjnych, brak zróżnicowania praktyk narracyjnych ze względu na płeć (kulturową i biologiczna) czy grupę/klasę społeczną; semiotyczne ujęcie codzienności jako składnika tożsamości narracyjnej.

Słowa kluczowe: narracja, narratywizm, tożsamość, tekst, praktyka piśmienna, codzienność, Barthes Roland, Parker David, Taylor Charles

\section{Tożsamość i języki dobra}

Rozdział z książki Davida Parkera The Self in Moral Space: Life Narrative and the Good, zatytułowany Narracja autobiograficzna i jezyki dobra, daje do myślenia. Parker stawia pytanie, „w jaki sposób uchwycić jak najlepiej sens życia”. Następnie pokazuje, że nie da się uchwycić sensu życia inaczej niż przez odniesienie do przestrzeni wartości, a konkretnie do „języków dobra”, które są według niego niezbywalnym składnikiem (czy raczej punktem odniesienia) każdej autobiograficznej narracji o życiu, sprawiającym, że życie to daje się wysłowić jako mające znaczenie.

Zarówno dla Parkera, jak i - zwłaszcza - dla Charlesa Taylora, na którego Parker się powołuje - bardzo ważne jest takie „umiejscowienie” języków dobra, aby stanowiły one zarazem przestrzeń wartości konstytutywnych, czyli takich, których istnienie nie jest warunkowane indywidualnymi wyborami czy decyzjami (albo preferencjami, tak jak w preferencjalizmie Rolanda Barthes'a) i które nawet jeśli nie da się o nich mówić jako o obiektywnych czy absolutnych, są realne i intersubiektywne, a zarazem „sprawdzalne” praktycznie - w przestrzeni życia codziennego.

Problem wyrażający się w pytaniu „kim się jest” okazuje się dla Parkera (tak jak dla Taylora) problemem związanym z pewną postacią wiedzy. Pytanie o to, kim się jest, ma charakter „poznawczy”, przy czym poznanie ma specyficzną postać, jest nakierowane nie na zewnątrz, w stronę świata, ile do wewnątrz w stronę samego siebie. Tożsamość, będąc kwestią wiedzy, jest też zatem problemem języka, bowiem wiedza ta musi zostać jakoś wypowiedziana, wyrażona, skonstruowana. Sens życia musi zatem przybrać postać ekspresji językowej, wysłowionej lub nie, uzewnętrznionej lub realizującej się w przestrzeni świadomości. Ostatecznie, według Taylora i Parkera, wiedza o sobie samym, wiedza 
tożsamościowa, przybiera postać narracji, czyli opowieści o własnym życiu, której nie sposób skonstruować bez odniesienia do wartości, przynajmniej wtedy, kiedy chce się nadać jej sens zakładający odwołanie się do jakiegoś etycznego porządku. Tożsamość zachowująca swoją elementarną spójność musi być tak czy inaczej tożsamością istniejącą w przestrzeni moralnej. Inaczej byłaby naznaczona chaosem, rozpadem i przypadkowością, a więc zatraciłaby podstawowe cechy tożsamościowe.

Taylor proponuje (...) eksperyment myślowy: spróbujmy wyobrazić sobie kogoś nieukierunkowanego na żadne silnie wartościowane dobra. Byłby to człowiek niezdolny do rozstrzygnięcia, co warto zrobić, a czego nie warto, co jest dobre, a co złe, co istotne lub drugorzędne. Chodzi nie tylko o to, że ktoś taki byłby powierzchowny czy niefrasobliwy w kwestiach moralnych, lecz o to, że byłby pogrążony w potężnym „kryzysie tożsamości” i miałby głęboko, wręcz patologicznie zdezorientowaną psychikę, pozostając poza tym, co uznalibyśmy za normę. Stosunkowo normalny człowiek musi orientować się jakoś w przestrzeni moralnej: „horyzonty, wewnątrz których żyjemy, muszą obejmować mocne rozróżnienia jakościowe”. Bez takich horyzontów trudno w ogóle rozpoznać w kimś „osobę” czy "podmiot"1.

Co do tej ostatniej kwestii zgadzam się, choć jedynie do pewnego stopnia, zarówno z Parkerem, jak i z Taylorem. Ja również sądzę, że poczucie tożsamości jest zasadniczo niemożliwe bez horyzontu wartości, który naszą tożsamość czyni możliwą. Można by tu też mówić o horyzoncie czy porządku kultury - w takim sensie, w jakim pisał o niej Henryk Elzenberg. Właśnie ład aksjologiczny, świat wartości jako nieredukowalny składnik porządku ludzkiego świata był dla niego jednym z najważniejszych przejawów istnienia kultury.

Nie zgadzam się zarazem z trzema przesłankami takiego stwierdzenia, które dostrzegam (być może niesłusznie) w koncepcjach Taylora i Parkera. Po pierwsze uważam, że istnienie przestrzeni moralnej i funkcjonujących w niej języków dobra jako niezbędny warunek doświadczeń tożsamościowych nie musi oznaczać wyraźnego uświadamiania sobie istnienia tej przestrzeni oraz posługiwania się tymi językami. Moim zdaniem nie ma koniecznego iunctim między świadomością etyczną a postępowaniem etycznym. Można mieć bardzo rozbudowaną, głęboką świadomość etyczną i postępować nieetycznie (na co w dzisiejszym świecie nie brak przykładów). Można też nie zdawać sobie sprawy z niuansów świata wartości, a na co dzień wcielać je w życie w postawach praktycznych (tak jak praktyczne użycie języka nie wymaga znajomości rządzących nim reguł). Parker, cytując Taylora, zwraca uwagę, że:

1 D. Parker, Narracja autobiograficzna i języki dobra, tłum. A. Skucińska, „Konteksty Kultury" 2021, t. 18, z. 1, s. 9. 
jeżeli jest się stosunkowo normalną osobą, to zna się swoje stanowisko wobec wielu nieuniknionych pytań o to, co jest dobre, a co złe, co godne podziwu, a co pogardy, co warto robić, czego nie warto, co ma znaczenie, co zaś jest banalne i drugorzędne. Odpowiedzi na te pytania definiują, kim jesteśmy, i nieuchronnie dotyczą dóbr silnie wartościowanych - tego, co postrzegamy jako ważne czy znaczące w swoim życiu ${ }^{2}$.

Otóż moim zdaniem można być „stosunkowo normalną osobą” i nie zadawać sobie „pytań o to, co jest dobre, a co złe”, a od odpowiedzi na te pytania uzależniać kształtowanie własnej tożsamości. To nie znaczy, że kwestie etyczne nie są powiązane z procesami tożsamościowymi. Myślę, że są powiązane, ale przede wszystkim w przestrzeni praktycznych wyborów i rozstrzygnięć, a nie teoretycznych (świadomościowych) założeń. Innymi słowy, świadomość etyczna nie jest, moim zdaniem, niezbędna do tego, aby postępować etycznie, choć postępowanie etyczne lub nieetyczne w istotny sposób kształtuje naszą tożsamość.

Z tym wiąże się kolejna kwestia. Parker i Taylor zakładają, że przestrzeń etyczna daje się wysłowić w sposób pojęciowy, przybierając postać katalogu dóbr konstytutywnych. I że nasza tożsamość kształtuje się wobec tak ujętych pojęciowo wartości, przede wszystkim wobec dobra. I to założenie budzi moją wątpliwość. Sądzę, iż obaj autorzy ekstrapolują podejście filozoficzne, które reprezentują (a filozofia to przede wszystkim praca na pojęciach) na zagadnienia, o których piszą. Dlatego świat wartości i związanych z nimi postaw moralnych jest przez nich traktowany pojęciowo. Taylor co prawda w swojej fundamentalnej rozprawie Źródta podmiotowści (wciąż inspirującej, po przeszło 30 latach od jej wydania) wprowadza kategorię praktyki, ale nie czyni z niej jednak ostatecznie kategorii ważnej dla swojej koncepcji „tożsamości nowoczesnej” (znaczący jest fakt, że nie znalazła się ona nawet w bardzo rozbudowanym skorowidzu pojęć na końcu książki ${ }^{3}$ ).

Przedmiotem mojego zainteresowania - pisze Taylor - są różne idee - ideały moralne, koncepcje podmiotu i rozumienie kategorii człowieczeństwa - które są obecne w naszym życiu poprzez to, że są zakotwiczone w rozmaitych praktykach. Przez „praktykę” rozumiem coś skrajnie nieokreślonego i ogólnego; na własny użytek mogę to w przybliżeniu zdefiniować jako każdy stały, rozpowszechniony układ ludzkich działań, którego kształt określony jest przez pewien wzorzec. (...)

2 Tamże, s. 19.

3 Podobna sytuacja występuje w nowszej książce Charlesa Taylora The Language Animal: The Full Shape of the Human Linguistic Capacity (Cambridge-London 2016). I tu pojawia się kategoria praktyki, tym razem w odniesieniu do koncepcji Pierre'a Bourdieu. Jednak i tym razem kategoria ta nie staje się dla Taylora kategorią pierwszoplanową (i znów brak dla niej miejsca w rozbudowanym indeksie pojęć). 
Podstawowa relacja polega na tym, że idee stanowią artykulację praktyk jako pewnych wzorców. Idee często rodzą się zatem z prób określenia i świadomego wypowiedzenia ukrytych racji bytu owych wzorców. (...) jako artykulacje idee są w pewnym istotnym sensie wtórne, czy też pochodne wobec wzorców ${ }^{4}$.

Mimo że Taylor zakłada pierwotność praktyk względem idei, to dalej w jego koncepcji w niewielkim stopniu znajdzie to swoje rozwinięcie. Dzieje się tak między innymi dlatego, że zarówno Taylor, jak i Parker pracują przed wszystkim na źródłach, które mają postać ekspresji tekstowych i to bardzo szczególnego rodzaju: na źródłach filozoficznych i literackich. Zdają się oni zarazem nie dostrzegać, że sam charakter tych źródeł warunkuje w dużym stopniu to, co zostanie w nich wyrażone. Idee i wartości jako kategorie rozumienia oraz oceniania świata i człowieka stanowią niewątpliwe rezultat długiego procesu rozwoju kultury piśmiennej. W odniesieniu do idei i wartości religijnych pokazał to na przykład przekonująco Jack Goody, porównując religie oralne i religie pisma. Zwrócił między innymi uwagę na to, że „uniwersalizm etyczny”, który jest „właściwy nie tylko chrześcijaństwu, ale wszystkim religiom powszechnym”, wiąże się „bezpośrednio z używaniem przez nie pisma”, bowiem „charakter sformułowań pisanych sprzyja dekontekstualizacji i generalizacji norm"s. Tego rodzaju rozpoznania Goody'ego uwrażliwiają nas na inne, nie tyle „etyczne”, ile „emiczne” rozumienie postaw moralnych, mogących przybierać postać silnie skontekstualizowanych praktyk, którym nie towarzyszą zewnętrzne względem nich normy i wzorce.

Można powiedzieć, że Taylor i Parker przyjmują piśmienno-tekstową matrycę rozumienia człowieka i świata jako oczywistą (dlatego w dużej mierze przezroczysta) i to dopiero w jej obrębie dokonują, nierzadko bardzo subtelnych, rozróżnień. Matryca ta zakłada, że człowiek nowoczesny kształtuje swoją tożsamość wtedy, kiedy zdaje sobie sprawę z własnej wyjątkowości, kiedy potrafi w akcie autorefleksji rozpoznać sens swojego życia, co ostatecznie jest możliwe przez wpisanie tego życia w linearny porządek kolejnych zdarzeń, doświadczeń, wyborów, decyzji dokonywanych w horyzoncie rozpoznań moralnych czemu służy narracyjna opowieść o własnym życiu jako modelowa struktura tożsamościowa.

${ }^{4}$ Ch. Taylor, Źródta podmiotowości. Narodziny tożsamości nowoczesnej, tłum. M. Gruszczyński i in., oprac. T. Gadacz, wstęp A. Bielik-Robson, Warszawa 2001, s. 381-382.

5 J. Goody, Logika pisma a organizacja spoteczeństwa, tłum., wstęp i red. G. Godlewski, Warszawa 2006, s. 49. Dalej Goody pisze: „Gdy do komunikacji międzyludzkiej wkracza pismo, pojęcia dobra i zła zostają - choć nie od razu - zapisane i usystematyzowane w postaci kodeksu praw lub etyki. Ideały, wcielone raczej w tekst niż w kontekst, przestają tak ściśle wiązać się z aktualnymi zastosowaniami; może się utrzymywać dawna eschatologia, może też powstać nowa, sprzeczna - przypadkowo lub celowo, w sferze interesów lub co do samej istoty - z innymi częściami tradycji społeczno-kulturowej" (tamże, s. 59). 
Mam jednak bardzo silne wrażenie, że opisywana przez Taylora „tożsamość nowoczesna” jest tożsamością piśmienną, a samo pojęcie „podmiotu”, którym się posługuje, nie daje się pomyśleć poza pismem i poza tekstem. $Z$ jednej strony nie powinno być to nic zaskakującego, w końcu Taylor pisze o kulturze euroatlantyckiej, która została zbudowana na piśmie i druku. Problem polega na tym, że Taylor, tak obszernie opisując „źródła podmiotowości”, w ogóle nie zwraca na to uwagi. A przecież najważniejsze, niewypowiedziane, a zarazem bezwiednie absolutyzowane przez Taylora „źródła podmiotowości”, jako podstawy tożsamości nowoczesnej, to źródła piśmienno-tekstowe, które nie są jedyne. Uświadamia nam to cała wielka tradycja badań oralności/piśmienności, składająca się z prac takich autorów, jak chociażby Marshall McLuhan, Walter J. Ong, Jack Goody, Eric Havelock, David R. Olson, Roy Harris, a z polskich autorów Grzegorz Godlewski. Niestety, tradycja ta w pracach Taylora jest całkowicie nieobecna ${ }^{6}$.

Dlaczego tak się dzieje? Nie dlatego przecież, aby Taylor uważał, iż jest możliwa jakaś wiedza, czy też jakieś postaci świadomości całkowicie zdekontekstualizowane, czy to historycznie, czy społecznie, czy psychocieleśnie. Przeciwnie. W Language Animal wprowadza pojęcie „embodied understanding” (ucieleśnionego rozumienia), w Źródtach podmiotowości wspomina o „sieciach rozmowy", a dla spraw, o których pisze, dodaje kontekst zmian gospodarczych, społecznych, religijnych. A jednak w tej bardzo rozbudowanej panoramie pomija, co jest zaskakujące, kwestie zmiennych mediów słowa i związanych z nimi praktyk. A przecież to właśnie dzięki każdorazowo medialnie określonym praktykom słowa i poprzez nie - praktyki pisania, praktyki drukowania, praktyki lektury, praktyki rozmowy - idee i wartości, które analizuje Taylor, mogą zaistnieć i funkcjonować w przestrzeni międzyludzkiej. Gdyby tę kwestię wyostrzyć, można by powiedzieć - choć zdaję sobie sprawę z tego, że mogę być niesprawiedliwy, absolutyzując własne, medialne podejście do tych zagadnień że Taylor, pisząc o podmiotach, ma na względzie myślące, czujące, a do pewnego stopnia także działające ciała, natomiast w bardzo niewielkim stopniu podmioty praktyk komunikacyjnych.

Tu dochodzę do trzeciej kwestii, która budzi mój największy sprzeciw. Jest to teza o narracyjnym charakterze jednostkowej tożsamości. Stanowi ona do pewnego stopnia konsekwencję dwu poprzednich założeń mówiących o tym, że tożsamość jest związana ze samoświadomością oraz z językiem. Językowa postać świadomości samego sobie przybiera postać narracji. Wydaje mi się, że teza ta jest wynikiem założenia, iż między tożsamością i autobiograficznością istnieje wyraźne iunctim, co następnie ma swoje konsekwencje w przeniesieniu formy autobiograficznej opowieści na tożsamość tak, że narracyjność tej pierwszej decyduje o narracyjności drugiej. Tymczasem, po pierwsze, jedynie

${ }^{6}$ W Źródtach podmiotowości odwołanie do Waltera J. Onga pojawia się tylko raz (s. 348), jednak bez odniesienia do wspomnianej problematyki. 
autobiografia rozumiana wąsko, jako retrospektywna opowieść o własnym życiu, oparta jest (i to nie wyłącznie) na modelu narracyjnym. Autobiografia rozumiana szeroko i obejmująca takie formy autobiograficzne, jak dzienniki, notatniki czy listy już narracyjna w żadnym wypadku być nie musi. Po drugie, tożsamość nie musi być rozumiana ani narracyjnie, ani w ogóle linearnie, co skądinąd bardzo dobrze pokazują dzienniki intymne. Obiema tymi kwestiami zajmę się obszerniej w ostatniej części tego artykułu.

\section{W stronę tożsamości relacyjnej i performatywnej}

Tymczasem wracam do tekstu Davida Parkera, bowiem zasługuje on na osobne potraktowanie, podczas gdy w pierwszej części stanowił dla mnie jedynie punkt wyjścia do bardzo ogólnych rozważań, a w części trzeciej stanie się z kolei pretekstem do bliższego przyjrzenia się koncepcjom narratywistycznym i dyskusji z nimi.

Książka Davida Parkera The Self in a Moral Space: Life Narrative and the Good została:

pomyślana - tak prezentuje ją polskiemu czytelnikowi Łukasz Tischner - jako przywrócenie „wypartego" (etyki) poprzez pogłębione interpretacje dzieł literackich. Dotyczy ona narracji autobiograficznych (life narratives), które Parker traktuje jako teksty artykułujące - wprost lub pośrednio - „mocno wartościowane” dobra?.

Parker analizuje w książce takie teksty autobiograficzne, jak Wyznania Świętego Augustyna, Ecce homo Friedricha Nietzschego, Preludium Williama Wordswortha, Mojego ojca Romulusa Raimonda Gaity, Chtopięce lata Johna Maxwella Coetzeego, czy wreszcie Autorelacje Wang Schimina oraz „antyautobiografię" Rolanda Barthes'a. Komentarze do tych dwóch ostatnich pozycji znalazły się w polskim tłumaczeniu obszernych fragmentów rozdziału Narracja autobiograficzna i jezzyki dobra, więc nimi właśnie zajmę się przede wszystkim.

Autorelacja Wang Schimina to zaledwie ośmiostronicowy tekst pochodzącego ze słynnej i bogatej rodziny Wangów cenionego malarza, tworzącego w XVII wieku (1592-1680). Parker pokazuje, że podmiot wpisany w autobiograficzną relację Wanga jest „zorientowany na dobra silnie wartościowe”, spomiędzy których najważniejszy jest honor rodziny: „»Honor" jest w całym jego

Ł. Tischner, Perspektywa etyczna $w$ badaniach nad literatura $i$ religia. Redukcja czy konieczne dopetnienie? [w:] Literatura a religia - wyzwania epoki świeckiej, t. 1: Teorie i metody, red. Ł. Tischner, T. Garbol, Kraków 2020, s. 576. 
sprawozdaniu kluczowym dobrem, które tworzy horyzont znaczenia, kontekst implicytnej oceny wszystkich relacjonowanych czynów"

Parker zwraca zarazem uwagę na to, że Wang, jaki wyłania się z jego autobiograficznej relacji, to podmiot relacyjny, funkcjonujący $\mathrm{w}$,sieciach rozmowy” oraz określony przez odgrywane przez siebie role społeczne: „jedyny mężczyzna w rodzinie, syn, wnuk i urzędnik, w dokładnie rozrysowanej moralnej przestrzeni wartości konfucjańskich”. Można więc powiedzieć, że Parker sytuuje Wanga - za nim samym - w przestrzeni moralnej o dwóch wyraźnych płaszczyznach: wertykalnej (honor jako dobro silnie wartościowane) oraz horyzontalnej (realizacja zasad honoru i etykiety w codziennym życiu). Okazuje się jednak, że perspektywa horyzontalna „rzuca cień” na perspektywę wertykalną. Sam Parker pisze wprost, że wartości, którymi kierował się w swoim postępowaniu Wang Schimin, ,były przesiąknięte ideologią i nie tylko nie uwzględniały kobiet i sług umożliwiających funkcjonowanie tego tradycyjnego systemu uczonych o szlachetnym rodowodzie, ale także sankcjonowały ich wyzysk". Komentując to własne spostrzeżenie, które wydaje mi się bardzo istotne, Parker osłabia jego moc, pisze, iż samo dostrzeżenie tego faktu „też opiera się na wartościach i silnie wartościowanych dobrach, takich jak należny każdemu szacunek". A następnie dokonuje nawet zbliżenia postawy Wang Schimina i tego, kto dostrzega nieoczywistość honoru jako „silnie wartościowanego dobra”:

Wcielanie jej [refleksji o należnym każdemu szacunku - dop. P.R.) w życie wymaga tych samych procesów namysłu, osądu, oceny ludzi i postępowania, z którymi mierzył się Wang Shimin i z którymi musi się mierzyć każdy człowiek. Do tych właśnie procesów i do uchwycenia sensu naszego życia potrzebujemy gęstych języków wartości i dobra?.

Wydaje mi się, że Parker nie dostrzega konsekwencji takiego stawiania sprawy. Jeśli bowiem, z jednej strony, honor rodziny, którego realizacją w relacjach międzyludzkich może być brak szacunku dla osób z konkretnych grup czy klas społecznych, oraz - z drugiej strony - dostrzeganie w każdym człowieku osoby zasługującej na szacunek, mogą być postrzegane jako równie „silnie wartościowane dobra”, to „dobro” przestaje mieć tu uchwytną treść, będąc całkowicie zrelatywizowane do określonego kontekstu historycznego i kulturowego. Możemy oczywiście założyć, że „gęste języki wartości i dobra” zakładają ich wzajemną różnorodność - to jest zrozumiałe. Nie możemy jednak uznać, że mogą być one wzajemnie sprzeczne, bo wtedy same pojęcia „języków wartości i dobra” czy „przestrzeni moralnej” staną się problematyczne. Jest to oczywiście pytanie o granice relatywizmu. Moim zdaniem nie trzeba zajmować stanowiska absolutyzmu czy uniwersalizmu moralnego, tak jak nie zajmuje go

8 D. Parker, dz. cyt., s. 24.

9 Tamże, s. 27. 
Parker, a jednak przyjąć zasadę, w myśl której jakikolwiek relatywizm w myśleniu o świecie wartości musi oprzeć się na czymś, co go przekracza, za swą nieredukowalną podstawę przyjąć poszanowanie godności drugiego człowieka. Tam, gdzie takiego poszanowania nie ma, można mówić o „języku wartości”, ale nie o „języku dobra”.

Książce Rolanda Barthes’a David Parker poświęca zdecydowanie więcej miejsca. Traktuje ją jako „przypadek graniczny, który świadczy, że przy swoim nastawieniu do wartości Barthes nie może się całkowicie obyć bez silnie wartościowanych dóbr i warunkowanej przez nie potrzeby uchwycenia sensu swojego życia jako toczącej się opowieści”" ${ }^{\prime \prime}$. Od razu zaznaczę, że jeśli zgadzam się z pierwszą częścią tego stwierdzenia (niezbędne umiejscawianie się w przestrzeni moralnej), to nie sądzę, aby jej konieczną konsekwencją była część druga (potrzeba rozumienia siebie poprzez strukturę autobiograficznej opowieści).

Parker ma rację, kiedy pokazuje, że preferencjalizm Rolanda Barthes’a jest nie do utrzymania. Nie da się bowiem konsekwentnie podtrzymywać, że „świat i podmiot to nic więcej jak »kawałki«, czytelne jedynie w obrębie wielkiego tekstu systemów językowych”. Przypadkowość, płynność, zmienność, arbitralność pozycji komunikacyjnej podmiotu nie unieważniają samego podmiotu i jego tożsamości, która - niezależnie od tego, że i ona może być płynna i zmienna - musi posiadać pewną stabilność, choć nie musi to być stabilność (tak jak zakłada Parker) rozpoznawalna w kategoriach określonej znaczącej struktury (na przykład struktury autobiograficznej). Zgadzam się z Parkerem, że u Barthes'a „poprzez szczeliny w jego stylowo preferencjalistycznym metadyskursie przebłyskuje nam podmiot w przestrzeni moralnej”. Nie zgadzam się jednak, że podmiot ten wyłania się w narracji autobiograficznej i przez nią niejako jest ustanawiany. Nie znaczy to jednak, że nie zgadzając się z Parkerem, dzielę poglądy z Barthes'em, który - jak zauważa Parker - „ze swojej semiologicznej perspektywy postrzega podmiot jako rozproszony, jako zwykła "mozaikę reakcji« bez czegokolwiek "pierwotnego " "11. Nie, z tym również się nie zgadzam! Jak to możliwe?

Aby odpowiedzieć na to pytanie, zaczać trzeba od tego, jak Parker traktuje książkę Barthes’a. Otóż traktuje ją bardzo wybiórczo - jako zbiór mozaikowych fragmentów tekstowych, które jednak decydują o jej kształcie tylko do pewnego stopnia. Warto pamiętać, że książka Roland Barthes par Roland Barthes ukazała się w roku 1975 jako 96. pozycja w serii „Écrivains de toujours”, wydawanej od

\footnotetext{
10 Tamże, s. 28.

11 Tamże, s. 37.
} 
roku 1951 przez Éditions du Seuil. W serii tej ukazywały się pozycje prezentujące sylwetki wybitnych pisarzy i filozofów (przede wszystkim nieżyjących, wyjątkowo również żyjących) poprzez wybór ich własnych tekstów (często o charakterze autobiograficznym), a także zdjęć i dokumentów z epoki. Całość była uzupełniona przez krótki, przedstawiony w porządku dat, biogram oraz bibliografię omawianej postaci. Prezentacja ta miała niejako dwóch autorów: autora-redaktora książki (na przykład 29. pozycję w tej serii z roku 1955, poświęconą Jeanowi-Paulowi Sartre’owi, przygotował Francis Jeanson) oraz głównego bohatera-autora większości tekstów (w tym przypadku Sartre’a). Sam Roland Barthes przygotował wcześniej dla tej serii (pozycja 19, rok 1954) książkę poświęconą Jules'owi Micheletowi. Potem, po 11 latach, przygotował z kolei tom poświęcony... sobie samemu. Miał on już teraz nieco inny tytuł, bowiem od roku 1972 zrezygnowano z formuły par lui-même, zastępując ją samym par, co dało w tym przypadku Roland Barthes par Roland Barthes. Po raz pierwszy i ostatni w „Écrivains de toujours” pojawił się tom, którego autor i bohater byli tą samą osobą, przez co nastąpił „powrót do sytuacji autobiograficznej w ramach kolekcji »biograficznej«, która zamierzała na początku odtwarzać autoportret autora" ${ }^{12}$. Sytuacja autobiograficzna w ramach kontekstu kolekcji biograficznej nie zakłada napisania autobiografii, dlatego też nie sądzę, aby Roland Barthes par Roland Barthes miał być koniecznie nazywany ,antyautobiografią”.

Barthes - zauważył trafnie cytowany już wyżej Philippe Lejeune - pragnął maksymalnej elastyczności, obawiając się wpaść w pułapkę swoich „wyobrażeń”. Napisał sam o sobie książkę krytyczną, w kolekcji o statusie niejasnym: reguły gry przewidują, że krytyk zrekonstruuje „Kogoś przez niego samego”, dokonując montażu tekstów, ale ten autoportret pozostaje zależny od dyskursu krytyka. Co stanie się, jeśli sam autor wślizgnie się w rolę krytyka? Tego właśnie próbował Barthes: czyta ponownie swoje własne dzieła z ołówkiem w ręku, przygląda się sobie, pisze na nowo, stara się ujść ciążeniu „ja” przez nieustanne wariacje zaimków osobowych (kolejno „ja”, „pan” [vous], „on”, „R.B.”), a zarazem teoretyzuje i krytykuje tę praktykę ${ }^{13}$.

Barthes do pewnego stopnia podporządkował się regułom obowiązującym w serii. Tak jak inne zamieszczone w niej pozycje jego książka stanowi kompozycję złożoną z tekstów, zdjęć, fotokopii dokumentów, rysunków, rycin, partytur muzycznych, rękopisów. Kształt tej publikacji jest moim zdaniem bardzo ważny.

${ }^{12} \mathrm{Ph}$. Lejeune, Autobiografia w trzeciej osobie, tłum. S. Jaworski [w:] tegoż, Wariacje na temat pewnego paktu. O autobiografii, tłum. W. Grajewski i in., red. R. Lubas-Bartoszyńska, Kraków 2001, s. 142. Dalej Lejeune pisze: „Nie należy pomieszać tej sytuacji z inną, o wiele bardziej rozpowszechnioną i prostszą, tych kolekcji, które od razu domagają się od autorów, aby mówili o sobie i o swoich utworach" (tamże).

13 Tamże, s. 141-142. 
Już sam fakt, że tak dużą, jej początkową partię stanowią zdjęcia, pokazuje, że nie da się jej rozpatrywać w sposób tekstowy. To jest książka nie tylko do czytania, ale także do oglądania. Doszukiwanie się narracyjności u Barthes’a jest możliwe, kiedy najpierw zredukuje się jego dzieło do tekstu albo będzie się rozumiało narracyjność bardzo szeroko, co pozwoli na postrzeganie jako narracyjnej na przykład samej sekwencji obrazów (od razu dodam, że takie szerokie rozumienie nie jest mi bliskie).

Książka Barthes’a nie jest tekstem. Można powiedzieć, że jest połączeniem tekstów i obrazów, ale i to nie jest do końca słuszne. Jest jeszcze czymś więcej, co ujawnia się szczególnie wyraźnie w zamieszczonych w niej wizerunkach rękopisów i rysunków. Do nich przejdę za chwilę, teraz zostanę jednak jeszcze przy książkowości projektu Barthes’a. Jeśli książkowość tę potraktujemy jako możliwą formę tego, co autobiograficzne, to zobaczymy, że to, co autobiograficzne, może być bardzo heterogeniczne (zestawienie bardzo różnych elementów) oraz przybierać bardziej kształt przypominający archiwum czy kolekcję niż ciągły tekst.

$\mathrm{Z}$ tym wiąże się kwestia linearności. Dzieło Barthes'a dalekie jest od modelu linearnej ciągłości tekstualnej. $Z$ jednej strony ciągłość ta jest, co prawda, zachowana przez kodeksową formę książki z kolejnymi następującymi po sobie kartami i ponumerowanymi stronami (linearna ciągłość/nieciągłość przestrzenna), przez „zbliżony do alfabetycznego” układ haseł oraz do pewnego stopnia przez czas historyczny (daty pojawiające po ostatnim zapisie: 6 sierpnia 19733 września 1974). Wszystko to są przejawy ciągłości narzuconej (określonej) przez zewnętrzne ramy (książka, kalendarz, alfabet). A w ich obrębie pojawia się to, co nieciagłe i fragmentaryczne (złożenie elementów o różnorakim charakterze, w tym kolejnych cząstek tekstowych). Gdyby teraz tę ciągło-nieciągła całość odnieść do tego, co autobiograficzne, to, jak sądzę, można by jego przejawy dostrzec nie tyle w opisywaniu swojego życia (jakkolwiek problematycznie by ono tu wyglądało) czy w jego przedstawianiu/ewokowaniu przy użyciu fotografii (co samo w sobie nie jest oczywiste), ale w samym charakterze projektu Barthes'a, w samym geście, a raczej praktyce autobiograficznej jako praktyce nie tekstowej, ale książkowej (choć sam Barthes być może nie życzyłby sobie takiego „osłabiania” tekstowego wymiaru jego książki).

Wracam zatem na poziom tekstu, by powiedzieć, że w tym wypadku znowu zgadzam się z Parkerem. Zauważa on, że „to, od czego Roland Barthes stroni w narracji, odkrywamy w swoistej mozaice fragmentów, "porządku wyobrażenia«, który ukazuje tożsamość przez formy reakcji i refleksji - oraz przez występujące w nich anomalie" 14 . Dalej Parker przekonująco pokazuje, jak w reakcjach, wyborach, stanowiskach, ja powiedziałbym: w różnego rodzaju praktykach, ujawnia się, niejako bezwiednie, tożsamość autora książi. Dopowiada zarazem, że Barthes'owskie „mozaikowe fragmenty” nie potrafią , unicestwić

${ }^{14}$ D. Parker, dz. cyt., s. 34. 
opowiadanej tożsamości, podmiotu jako rozwijającego się w czasie”. Takie odczytanie dzieła Barthes’a jest konsekwencją przyjętego przez Parkera - za Taylorem - założenia, że tożsamość nowoczesna tworzy się poprzez aktywność narracyjną, przybierając ostatecznie postać rozwijającej się w czasie opowieści. Moim zdaniem jest to założenie zbyt daleko idące.

Zanim to stwierdzenie rozwinę, chciałbym jeszcze przyjrzeć się pozostałym elementom w książce Barthes'a, o których można powiedzieć, że są do pewnego stopnia tekstowe i nietekstowe zarazem: rękopisom i rysunkom. Wydaje się, że sam Barthes chciałby je widzieć jako elementy tekstowe, oparte na językowym mechanizmie wytwarzania znaczeń. A jednak ich cielesność i materialność odsyła nas do innego rozumienia języka, które nie daje się zredukować do jego symbolizmu czy znakowego charakteru (na co skądinąd wskazywał bardzo wyraźnie Taylor w The Language Animal) ${ }^{15}$, a zarazem każe być może w ogóle podać w wątpliwość język jako jedyny czy najważniejszy wyznacznik tożsamości i komunikacji.

W kontekście praktyki pisania zwracał na to uwagę André Leroi-Gourhan w swojej słynnej książce Le geste et la parole, twierdząc, że „ekspresja graficzna przywraca językowi wymiar tego, co nie daje się ująć w słowach" ${ }^{16}$. Komentująca Leroi-Gourhana Marta Rakoczy w swoim artykule Materia, ciato, wizualność, czyli jak zrozumieć pisanie podkreśliła rzecz o kapitalnym znaczeniu:

czynność pisania nie wyczerpuje się w symbolizmie językowym, a dokładnie w użyciu słów zmaterializowanych na jakiejś powierzchni. Posiada ona pozajęzykowe komponenty związane ze szczególnym, zmiennym historycznie i kulturowo użyciem ciała, materii i wizualności ${ }^{17}$.

Dalej Marta Rakoczy pisze o kaligrafii, ale my możemy odnieść te słowa do wizerunków graficznych u Barthes’a. Otóż można powiedzieć, że jeśli w mozaikowych fragmentach tekstowych Barthes postępuje zgodnie z zasadą „odcieleśnienia i odmaterializowania czynności pisania” ${ }^{18}$, to poprzez obecne w książce wizerunki rękopisów i rysunków to, co cielesne i materialne, powraca, ujawniając

15 Taylor pisze: "linguistic capacity is essentially more than an intellectual one; it is embodied: in enacted meanings, in artistic portrayals, in metaphors which draw on embodied experience, and also in the iconic gestural portrayal which accompanies everyday speech, not to mention the ubiquity of "body language" - tone of voice, emphasis, expressive gesture, stances of intimacy, of aloofness - which surround ordinary discourse" (tenże, The Language Animal..., dz. cyt., s. 333). Dziękuję Łukaszowi Tischnerowi za zwrócenie mi uwagi na ten fragment.

${ }^{16}$ A. Leroi-Gourhan, Gesture and Speech, wstęp R. White, tłum. A. Bostock Berger, Cambridge-London 1993, s. 200; cyt. za: M. Rakoczy, Materia, ciato, wizualność, czyli jak zrozumieć pisanie, „Teksty Drugie” 2015, nr 4, s. 14.

${ }^{17}$ M. Rakoczy, Materia, ciato, wizualność, czyli jak zrozumieć pisanie, „Teksty Drugie” 2015, nr 4, s. 14 .

${ }^{18}$ Tamże, s. 22. 
swoją dojmującą obecność, co szczególnie wyraziście objawia się na samym końcu, gdzie widzimy wykonane ręką samego Barthes'a, korespondujące ze sobą linie graficzne podpisane „Grafia bez celu” oraz „albo znaczące bez znaczonego” ${ }^{19}$. Mamy w nich do czynienia z „ujęciem pisma przede wszystkim jako tworzenia linii, a nie układania słów”20. Kilka stron wcześniej Barthes dodatkowo zamieścił rycinę z Encyklopedii Denisa Diderota, opisaną w spisie ilustracji jako „Anatomia: pnie żyły głównej z rozgałęzieniami w ciele dorosłej osoby" oraz opatrzoną przez samego autora-redaktora znaczącym podpisem (komentarzem): „Napisać ciało. Nie skórę, mięśnie, kości, nerwy, lecz resztę: zgrzebne, włókniste, kosmate, postrzępione "coś«, pelerynę klauna"21.

Ciało nie daje się tekstualizować. Pisząca ręka pozostawia dwa rodzaje znaków, dwa rodzaje śladów. Rozszyfrowanie jednych polega na ich zdekodowaniu, czyli wydobyciu znaczeń z zapisanych znaków mających postać językową. Rozszyfrowanie drugich jest o wiele trudniejsze, bowiem ich istnienie nie jest oparte na relacji między znaczonym i znaczącym. Te pierwsze są związane z procesami mentalnymi oraz z pojęciową werbalizacją intencji towarzyszących pisaniu. Te drugie z procesami psychosomatycznymi i fizjologicznymi, najczęściej nieintencjonalnymi, które pozostawiają po sobie jedynie poszlaki, ujawniające - jak ślady zwierząt czy ludzkich stóp na piasku - obecność kogoś, kto je pozostawił 2 .

Właśnie znaczące miejsce tego rodzaju podwójnych śladów w książce Barthes'a wskazuje na przenikające ją napięcie między tekstualnym (czy szerzej: językowym, czy jeszcze inaczej: świadomościowym, mentalnym) a psychosomatycznym doświadczaniem tożsamości. I nawet jeśli Barthes sam zapewnia, że „podmiot to tylko efekt języka”"23 - to jego książka temu przeczy. Nie, podmiot nie jest efektem języka. Jest rezultatem różnego rodzaju praktyk i doświadczeń, pośród których te o charakterze językowym zajmują ważne miejsce. Ważne, ale nie jedyne. Tak jak nie da się zredukować podmiotu do języka, tak nie da się zredukować tożsamości do narracji.

W tym sensie książka Rolanda Barthes'a jest bardzo pouczająca. Uświadamia nam ona, że szukając „medialnych” określeń tożsamościowych, można, zamiast po te określenia, które opierają się na języku - takie jak narracja czy opowieść - sięgnąć po inne, które zawierają wyraźny komponent „cielesny” oraz „relacyjny” (co oczywiście komponentu słownego nie wyklucza), takie jak praktykowanie czy performans. Widziana w tej perspektywie książka

${ }^{19}$ R. Barthes, Roland Barthes, tłum. T. Swoboda, Gdańsk 2011, s. 202 i 217.

${ }^{20}$ T. Ingold, Rysowanie, pisanie i kaligrafia, tłum. M. Rakoczy, „Teksty Drugie” 2015, nr 4, s. 373.

${ }^{21}$ R. Barthes, dz. cyt., s. 217 i 195.

${ }^{22}$ Przy takim rozumieniu znaków graficznych jako „poszlak” bardzo inspirujący może być artykuł Carla Ginzburga Tropy. Korzenie paradygmatu poszlakowego, tłum. T. Sierotowicz, „Zagadnienia Filozoficzne w Nauce" 2006, XXXIX, s. 8-65.

${ }^{23}$ R. Barthes, dz. cyt., s. 90. 
Roland Barthes par Roland Barthes byłaby przykładem takiego właśnie praktykowania tożsamości, piśmienno-typograficzno-wizualnego performansu, w którym Roland Barthes przedstawia (tak, raczej przedstawia, niż opisuje!) samego siebie. Tym bardziej że tytuł na okładce - Roland Barthes - który przecież ma charakter raczej ostensywny niż pojęciowy, jest niczym innym niż piśmienno-typograficznym gestem wskazującym na osobę autora.

\section{Wobec koncepcji narracyjnej tożsamości}

Charles Taylor w swojej fundamentalnej i (zasłużenie) traktowanej jako jedna z najważniejszych pozycji filozoficznych końca XX wieku rozprawie zatytułowanej Źródta podmiotowości. Narodziny tożsamości nowoczesnej jasno i dobitnie ujmuje kwestię narracyjnego charakteru tożsamości:

jako istota, która rozwija się i staje, mogę znać samego siebie tylko poprzez moją historię dojrzewania i regresji, historię zwycięstw i klęsk. Moje samorozumienie ma z konieczności czasowy wymiar i opiera się na narracji. (...)

nasze istnienie jako podmiotu jest ze swej natury powiązane z naszym pojmowaniem dobra (...), stać się podmiotem można jedynie pomiędzy innymi podmiotami. (...) kwestia naszego usytuowania wobec owego dobra jest naszą podstawową i nieuniknioną troską, (...) z konieczności staramy się nadać naszemu życiu sens czy treść, to zaś oznacza, że nieuchronnie pojmujemy samych siebie za pośrednictwem narracji. (...)

Można to wyrazić następująco: z konieczności musimy orientować się względem dobra, dlatego też nieuchronnie próbujemy określić nasze miejsce w stosunku do niego, a także nadać kierunek naszemu życiu, stąd zaś wynika, że musimy pojmować nasze życie w formie narracji, jako „poszukiwanie”. Można by też chyba zacząć od innej strony: ponieważ musimy określać nasze miejsce względem dobra, nie możemy obejść się bez orientacji wobec niego, a zatem musimy postrzegać nasze życie jako opowieść. Z którejkolwiek strony by zacząć, warunki te jawią się jako powiązane aspekty tej samej rzeczywistości, nieuniknione warunki strukturalne ludzkiego działania ${ }^{24}$.

Już z tego cytatu widać (a został on wyjęty z blisko 1000-stronicowej rozprawy, w której prezentowane stanowisko zostało wyłożone precyzyjnie i bardzo dobrze uargumentowane), że koncepcja Taylora, jak też w ogóle koncepcje narratywistyczne zasługują na bardzo poważną debatę, która - z tego co mi wiadomo -

${ }^{24}$ Ch. Taylor, Źródta podmiotowości..., dz. cyt., s. 100-104. 
do tej pory się nie odbyła. Siła tych koncepcji, ich wszechobecność ${ }^{25}$, a także atrakcyjność w propozycjach teoretycznych oraz skuteczność w działaniach praktycznych (na przykład w narracyjnych metodach terapii w psychoanalizie, psychiatrii czy medycynie ${ }^{26}$ ) sprawia, że poza wyjątkami, takimi jak tekst Galena Strawsona Against Narrativity ${ }^{27}$, niewiele jest wystąpień krytycznych podważających te koncepcje czy choćby podających je w wątpliwość. Poniższe, bardzo wstępne i skrótowe komentarze mają ambicję nie tyle wypełnienia tej luki, ile zwrócenia uwagi na potrzebę dyskusji w tym zakresie ${ }^{28}$.

Pierwszy, najbardziej zasadniczy problem, jaki wyłania się z zacytowanego fragmentu książki Charlesa Taylora, a który zarazem pojawia się w różnych odmianach w koncepcjach narratywistycznych, to uprzywilejowanie procesów poznawczych w naszym doświadczaniu świata i doświadczaniu samego siebie. Przy takim podejściu zarówno świat, jak i nasze ,ja” stają się przedmiotem swoistej wiedzy w postaci samoświadomości, choćby była to wiedza rozumiana dynamicznie - jako wiecznie stająca się, wiecznie ponawiana odpowiedź na pytanie: czym jest świat, czym jest nasze „ja”, jakie są ich rozwijające się w czasie znaczenia? Tym samym narracja staje się „sposobem rozumienia świata” i „samorozumienia” nas samych. Trzeba jednak zauważyć, że takie nastawienie na rozumienie, bezwiednie przyjmowana i ponawiana postawa poznawcza chcąc nie chcąc „wyrywa nas” z doświadczania świata i doświadczania samych siebie w świecie. Doświadczanie to nie daje się w żaden sposób zredukować do procesów świadomościowych, ani też do procesów psycho-cielesno-świadomościowych, jest ono bowiem nade wszystko splotem wielu działań i praktyk, które

${ }^{25}$ Oczywiście Taylor nie jest ani pierwszym, ani ostatnim, który posługuje się kategorią narracji jako pozwalającą wyrazić sposób ujmowania, rozumienia i opisywania przez jednostkę zarówno świata, w którym żyje, jak i siebie samej. Narracja stała się kategorią tak ekspansywną, że zajęła istotne miejsce w przestrzeni bardzo wielu dyscyplin nauk humanistycznych, społecznych i medycznych, w tym w filozofii (Paul Ricœur, Alasdair McIntyre, Charles Taylor), historiografii (Hayden White, David Carr), literaturoznawstwie (Paul John Eakin, David Parker), psychoanalizie i psychologii (Roy Schafer, Donald P. Spence, Jerzy Trzebiński) czy medycynie (Rita Charon, Maria Giulia Marini, Lewis Mehl-Madrona). Zob. K. Rosner, Narracja, tożsamość i czas, Kraków 2003.

${ }^{26}$ Zob. choćby: Narracja jako sposób rozumienia świata, red. J. Trzebiński, Gdańsk 2002; Medycyna narracyjna. Opowieści o doświadczeniu choroby w perspektywie medycznej i humanistycznej, red. M. Chojnacka-Kuraś, Warszawa 2019; R. Charon i in., Medycyna narracyjna, tłum. M. Świątkowska, red. M.K. Potoniec, H. Syzdek, Kraków 2021.

${ }^{27}$ G. Strawson, Against Narrativity, „Ratio (new series)” 2004, nr 4 (XVII), s. 428-452.

${ }^{28}$ Poruszane w dalszej części artykułu problemy i próba wyrażenia mojego stanowiska wobec koncepcji narratywistycznych nie odnoszą się do jakiejś określonej ich postaci czy do jednego autora. Stanowią próbę wydobycia kilku ważnych wątków pojawiających się najczęściej w różnych odmianach i realizacjach narratywizmu oraz ustosunkowania się do nich. Poza tym odwołując się, najczęściej krytycznie, do koncepcji „narracyjnej tożsamości” jako składnika koncepcji konkretnych autorów, nie odrzucam ich myśli jako takiej. Na przykład bardzo sobie cenię prace Paula Ricœura czy Charlesa Taylora, choć prezentowany przez nich narratywizm nie jest mi bliski. 
mają oczywiście istotny wymiar psycho-cielesny i świadomościowy, a także wymiar intersubiektywny oraz komunikacyjny, dzieją się w sieci relacji międzyludzkich (wraz z relacjami z aktorami nieludzkimi, o których pisał Bruno Latour), które decydują o ich charakterze.

Drugi problem jest związany z pytaniem o źródła koncepcji narratywistycznych. Zauważmy najpierw, że w koncepcjach tych bardzo często pojawiają się takie kategorie, jak język, tekst, reprezentacja, konstrukcja, interpretacja, refleksja, lektura, wreszcie sama narracja. O czym to świadczy? Moim zdaniem jest to przejaw „nachylenia tekstowego”, specyficznego postrzegania świata i człowieka poprzez model tekstowy, co nie przypadkiem dokonuje się w kulturze rozwiniętej piśmienności, która skądinąd właśnie w istotny sposób zmienia swój charakter pod wpływem słowa elektronicznego i jego mediów. Grzegorz Godlewski słusznie zwraca uwagę, że:

Najbardziej rozwiniętym wytworem piśmienności jest tekst, zamknięty i samowystarczalny, powołujący do życia autonomiczny dyskurs, który ma znaczyć samodzielnie, niezależnie od kontekstu - w sposób pojęciowy i abstrakcyjny, w kategoriach ogólnych reguł i struktur, podporządkowanych zasadom logiki formalnej. Tak rozumiany tekst, właściwe siedlisko teorii, stał się matrycą myślenia, ośrodkiem piśmiennej episteme, wyznaczonej przez kategorie wywiedzione z tekstowej organizacji znaczenia i ustanawiającej kryteria prawomocności wiedzy i doświadczenia. Internalizacja tej episteme prowadzi do powstania nachylenia tekstowego - generalnej postawy poznawczej, zgodnie z którą na uwagę zasługują jedynie zjawiska spełniające te kryteria, sytuujące się w obrębie wytworzonej wcześniej stekstualizowanej reprezentacji teoretycznej świata ${ }^{29}$.

Oczywiście, ktoś mógłby powiedzieć, że moje uwagi są nadużyciem, a koncepcje narracyjnej tożsamości czy narracyjnego rozumienia świata nie mogą zostać zredukowane do modelu tekstowej opowieści o sobie czy świecie, bowiem wprowadzane przez nie kategorie narracji czy opowiadania wcale nie muszą być tekstowe, a pierwotnie pochodzą ze świata kultury oralnej. To oczywiście prawda. Jednak w koncepcjach narratywistycznych nie widzimy zwykle odwołania do pewnej sytuacji narracyjnej czy do rozumianego całościowo kontekstu narracyjnego, do narracji jako wydarzenia czy doświadczenia ${ }^{30}$, ale właśnie do narracji jako linearnej struktury znaczącej, będącej narzędziem naszym procesów mentalnych, mającej zatem tekstowy charakter.

${ }^{29}$ G. Godlewski, Luneta i radar. Szkice z antropologicznej teorii kultury, Warszawa 2016, s. 11. Zob. też: P. Majewski, Tekstualizacja doświadczenia. Studia o piśmiennictwie greckim, Warszawa-Toruń 2015.

${ }^{30}$ Tak dzieje się w narracyjnych metodach terapii w psychoanalizie, psychiatrii czy medycynie, które są dla mnie przekonujące. Zob. przypis $26 \mathrm{w}$ niniejszym artykule. 
Trzeci problem bardzo blisko łączy się z poprzednim. Jest to problem metod. Narratywiści najczęściej pracują na tekstach, tym samym przenosząc narzędzia wypracowane do badania tekstów na badanie kwestii związanych z poczuciem tożsamości czy rozumieniem rzeczywistości. Takie pojęcia, jak znaczenie, sens, interpretacja, reprezentacja czy analiza zwykle pojawiają się jako nierozłączny składnik tych koncepcji. Tym samym koncepcje narratywistyczne opierają się na badaniu wytworów tekstowych, a nie praktyk powołujących je do życia. Stąd tak ważne dla tych koncepcji będzie badanie struktur narracyjnych czy schematów narracyjnych (oba pojęcia: struktury i schematu są niewątpliwie piśmienne i tekstowe). Trzeba przyznać, że ten sposób użycia kategorii narracji został perfekcyjnie wykorzystany we współczesnej myśli filozoficznej przez takich autorów, jak Paul Ricœur ${ }^{31}$, Alasdair McIntyre ${ }^{32}$, Charles Taylor czy David Parker. A w myśli psychologicznej choćby przez wybitnego polskiego badacza Jerzego Trzebińskiego i jego współpracowników. Ich prace są dla mnie źródłem nieustannej inspiracji, ale też nieustannego sprzeciwu, a jedną z przyczyn tego sprzeciwu jest podejście metodologiczne, w którym sam przedmiot badania (tekst narracyjny) decyduje (i to najczęściej w sposób bezwiedny) o kształcie wywiedzionych z jego badania teorii, a także o sposobie badania i kategoriach w nim użytych. Dodatkowo w psychologii mamy do czynienia z wywoływaniem źródeł narracyjnych, kiedy w badaniach prosi się o opowiedzenie bądź opisanie historii swojego życia ${ }^{33}$. Samo w sobie nie jest to oczywiście niczym złym, przeciwnie - ma w polskich naukach społecznych długą i ważną tradycję. Problem zaczyna się wtedy, kiedy odpowiedź na prośbę o opisanie historii życia ma świadczyć o tym, że życie przeżywa się jako historię. Tym samym bowiem już w metodzie znajduje się założenie, którego dopiero chcemy dowieść.

Czwarty problem dotyczy podmiotu doświadczającego samego siebie i świata w sposób narracyjny. Chcąc nie chcąc, podmiot tekstowy to podmiot do pewnego stopnia wyizolowany, samotny, indywidualny. Charakteryzuje go to, co Taylor nazywa „wewnętrznością”, a co ja chciałbym widzieć raczej jako „wewnętrzność piśmienno-typograficzną". Taylor ma rację, że „wewnętrzność” to podstawa „tożsamości nowoczesnej”. Zasadą istnienia „wewnętrzności” jest samoświadomość siebie jako podmiotu (językowego i moralnego), a sama „wewnętrzność" uzyskuje kształt struktury znaczącej, struktury tekstowej. „Wewnętrzność” może więc być narracyjna, a tożsamość narracyjna to tożsamość podmiotu, który sam siebie uprzedmiatawia, wydobywając niejako

${ }^{31}$ P. Ricœur, Czas i opowieść, t. 3: Czas opowiadany, tłum. U. Zbrzeźniak, Kraków 2008; tenże, O sobie samym jako innym, tłum. B. Chełstowski, oprac. i wstęp M. Kowalska, Warszawa 2005.

32 A. MacIntyre, Dziedzictwo cnoty. Studium z teorii moralności, tłum., wstęp i przypisy A. Chmielewski, tłum. przejrzał J. Hołówka, Warszawa 1996.

${ }^{33}$ Dużo przykładów takich badań zostało przywołanych w książce Narracja jako sposób rozumienia świata. 
własne ,ja" z codzienności, z sieci relacji, w które podmiot jest uwikłany, wreszcie z czasowości nie tylko linearnie doświadczanej historii, ale i bardzo wielu rytmów cyklicznych (do czego jeszcze wrócę za chwilę). Nie ma wątpliwości, że w kontekście rozwoju subiektywności, poczucia wyjątkowości jednostki i wzrostu znaczenia jej wewnętrznego świata jako składnika tożsamości dokonującego się w kulturze nowoczesnej i do zrozumienia tych procesów kategoria narracji może być przydatna. Jednak, moim zdaniem, nie może być ona traktowana ani jako kategoria uniwersalna (tak jak uniwersalna nie jest tożsamość nowoczesna), ani jako kategoria jedyna czy najważniejsza, w sposób konieczny decydująca o naszej tożsamości („musimy postrzegać nasze życie jako opowieśc””, „musimy pojmować nasze życie w formie narracji”). Choćby rozwój mediów elektronicznych i nasilanie się różnych praktyk internetowych pokazują nam, do jakiego stopnia nasza tożsamość jest sieciowa, relacyjna, stanowiąca rezultat nieustanego „pozycjonowania” się wobec innych i zapośredniczona przez praktyki komunikacyjne ${ }^{34}$. Dlaczego by więc - albo zamiast, albo oprócz - kategorii tożsamości narracyjnej nie używać kategorii tożsamości relacyjnej czy tożsamości komunikacyjnej (w tym znaczeniu komunikacji, które związane jest $\mathrm{z}$ łacińskim communicare, zawierającym bardzo silny komponent relacyjny, związany z „dzieleniem się, byciem w łączności” ${ }^{35}$.

Piąty problem to znów problem podmiotu narracyjnej tożsamości. Zarówno w koncepcjach filozoficznych (na przykład u Ricœura czy Taylora), jak i w wielu ujęciach psychologicznych (na przykład w tomie Narracja jako sposób rozumienia świata) podmiot operacji narracyjnych jest rozumiany w sposób bardzo ogólny, a na jego określenie wymiennie, oprócz samego „podmiotu”, pojawiają się takie terminy, jak „jednostka”, „osoba”, „ja” czy „człowiek”. Brak jest w tych koncepcjach wyraźniejszego zróżnicowania praktyk narracyjnych (ich występowania lub nie, nasilenia, rodzajów etc.) ze względu choćby na płeć (kulturową i biologiczna) ${ }^{36}$ czy grupę/klasę społeczną ${ }^{37}$. Dzisiaj natomiast

${ }^{34}$ W Źródtach podmiotowości Taylora problematyka komunikacyjna zostaje zasygnalizowana przez odniesienie do „teorii działania komunikacyjnego” Jürgena Habermasa. Taylor pisze, że bliskie jest mu podejście, w którym „podmiotowość kształtuje się poprzez wymianę językową" (tenże, Źródta podmiotowości..., dz. cyt., s. 937), jednak podejście to nie znajduje w jego książce obszerniejszego rozwinięcia.

${ }_{35}$ Podobnie jak kategoria praktyki tak kwestia relacyjnego usytuowania podmiotu pojawia się w koncepcji Taylora i jest obecna w Źródtach podmiotowości. A jednak tak samo jak w tamtym wypadku, nie jest ona traktowana jako ważny, nieredukowalny składnik tej koncepcji, o czym świadczy choćby to, że również takich pojęć, jak „relacyjność”, „podmiot relacyjny” czy „tożsamość relacyjna" brak jest w obszernym skorowidzu.

${ }^{36} \mathrm{Na}$ różnicę między „typem narracji kobiecej” i „typem narracji męskiej” zwraca uwagę Piotr Filipkowski w książce Historia mówiona i wojna. Doświadczenie obozu koncentracyjnego w perspektywie narracji biograficznych, Wrocław 2010 (zob. s. 175-207).

${ }^{37}$ Na przykład odsłonięcia takich, dalekich od modelu narracyjnego, towiecko-zbierackich praktyk odnajdywania sensu własnego doświadczenia dokonuje Tomasz Rakowski w książce Łowcy, zbieracze, praktycy niemocy. Etnografia cztowieka zdegradowanego (Gdańsk 2009), traktującej 
coraz bardziej zdajemy sobie sprawę z tych zróżnicowań i z potrzeby nowych podejść umożliwiających ich jak najgłębsze odsłonięcie ${ }^{38}$.

Szósty problem jest nico innej natury. Powiedzmy, że dotyczy on codzienności, czy też zwyczajnego życia. „Afirmacja zwyczajnego życia” - to ważny składnik rozwijanej przez Taylora koncepcji tożsamości nowoczesnej, a zarazem tytuł jednej z pięciu dużych części jego książki. Zwyczajne życie to dla Taylora:

termin techniczny wprowadzony na oznaczenie tych aspektów ludzkiego życia, które wiążą się z produkcją i reprodukcją, to znaczy z pracą, wytwarzaniem rzeczy potrzebnych do życia i naszą płciowością, włączając w to małżeństwo i rodzinę ${ }^{39}$.

Przy takim ujęciu zwyczajne życie przeciwstawia się przede wszystkim życiu wyjątkowemu, które charakteryzuje mędrca lub świętego. Zwyczajne życie jest dostępne każdemu - tak jak każdemu jest (przynajmniej potencjalnie) dostępne przeżywanie swojego życia jako opowieści. Wydaje się, że nie można się tu do niczego przyczepić. Zwyczajne życie w kulturze nowoczesnej rzeczywiście zyskuje na znaczeniu i nie sposób wyobrazić sobie nowoczesnej tożsamości bez jego uwzględnienia. A jednak zwyczajne życie w rozumieniu Taylora wcale nie jest takie zwyczajne. Zwyczajne życie „winno być uświęcone” - pisze Taylor, odwołując się do tradycji protestanckiej. Zwyczajne życie powinno być generatorem sensu, nośnikiem ważnych dla człowieka znaczeń i wartości (co może się realizować przez doświadczenia religijne, kontakt z literaturą, sztuką, muzyką, zachowania altruistyczne czy przez poczucie jedności z natura). Tym samym Taylor nadaje zwyczajności dodatkowy wymiar, ujmuje ją semiotycznie, etycznie lub metafizycznie, bowiem dopiero taka codzienność będzie pasować do jego modelu narracyjnej tożsamości.

Czy można jednak „zwyczajność” ujmować niesemiotycznie? Wydaje się, że można, a próbę taką podjął Michel de Certeau w swojej książce Wynaleźć codzienność. Sztuki dziatania. Starał się on „wyśledzić” codzienność przez wydobycie na plan pierwszy tego, co zwykle spychane jest w otchłań nic nieznaczących, mniej czy bardziej rutynowych czynności, które nie dają się łatwo semiotyzować i przez to umykają naszej świadomości. Dlatego de Certeau zajął się nie religią, literaturą czy doświadczeniami epifanijnymi, ale „sztukami działania”, praktykami, a nie ich ekspresjami czy śladami, choć często tylko do tych drugich mamy dostęp. Nie powinniśmy jednak zapominać, że wskazują one na coś, co stało się już nieobecne:

o doświadczeniu mieszkańców okolic Wałbrzycha, bezrobotnych górników i zubożałych mieszkańców wsi, oraz o sposobach radzenia sobie z tym doświadczeniem.

${ }^{38}$ Zróżnicowane spojrzenie na narracyjność ze względu na płeć czy grupę społeczną jest do pewno stopnia obecne w socjologii narracyjnej. Zob. Narrative Sociology, red. L.J. Irvine, J.L. Pierce, R. Zussman, Nashville 2019.

${ }^{39}$ Ch. Taylor, Źródta podmiotowości..., dz. cyt., s. 391. 
Z pewnością przebieg wędrowania może być odwzorowany na planach miasta w sposób polegający na transkrypcji śladów (w jednym miejscu bardziej zagęszczonych, w innym ledwie widocznych) oraz trajektorii (przechodzących tędy, a nie tamtędy). Jednak owe gięte linie pisma oznaczają, podobnie jak słowa, wyłącznie nieobecność tego, co przeszło. Zapisy tras zatracają to, co było: sam akt przechodzenia. Czynność chodzenia, błądzenia czy „oglądania sklepowych wystaw”, innymi słowy, czynność przechodniów, zostaje przemieniona w punkty, stanowiąc na planie scalającą i odwracalną linię. Uchwycić więc można tylko pozostałość tej działalności, usytuowaną w nie-czasie jakiejś powierzchni, na którą jest ona projektowana. Owa widoczna pozostałość sprawia jednak, że niewidoczna staje się czynność, która umożliwiła jej zaistnienie. Takie utrwalenia są procedurami zapominania. Praktyka zostaje zastąpiona śladem. Zdradza on (zachłanna) zdolność systemu geograficznego do przekształcania działania w czytelność, powodując jednak zapomnienie pewnego sposobu bycia w świecie ${ }^{40}$.

Nie będzie zaskoczeniem, kiedy napiszę, że tak rozumiana codzienność nie da się wpisać w struktury narracyjnego doświadczania siebie i świata. Po pierwsze dlatego, że jest to codzienność „nieczytelnych” praktyk, niedających się ująć w językowe, a zwłaszcza piśmienne struktury rozumienia. Po drugie dlatego, że mamy tu do czynienia z praktykami, których istotą jest często albo przypadkowość i akcydentalność, albo - przeciwnie - sekwencyjność, powtarzalność, cykliczność - co uniemożliwia ich włączenie jako pełnoprawnych składników do linearnej struktury rozwijającej się w czasie opowieści. Wydaje się zatem, że koncepcje narracyjnej tożsamości pomijają już w punkcie wyjścia olbrzymią część naszego codziennego doświadczenia. Śniadania czy kolacje nie mają swojej historii, a ich znaczenie dla kształtowania się naszej tożsamości - rozumianej całościowo, a więc psychofizycznej, relacyjnej i komunikacyjnej jednocześnie - jest przecież zupełnie podstawowe.

Siódmy i ostatni problem daje się sprowadzić do pytania: co z tym wszystkim zrobić? Czy uznać, że koncepcje narratywistyczne są do niczego nieprzydatne, więcej zaciemniają niż rozjaśniają? Nie, z pewnością nie. Moim zdaniem koncepcje te mogą być dla nas przydatne, jeśli przyjmiemy, że pokazują one, iż poznawanie świata przez narracyjną opowieść czy ujmowanie przez nią swojego życia i tożsamości staje się w kulturze nowoczesnej pewną istotną dyspozycją jednostki, dyspozycją, która ani nie jest uniwersalna, ani nie realizuje się zawsze w ten sam sposób (a może się też w ogóle nie realizować), ani nie tłumaczy nam sama przez się tego, czym jest tożsamość nowoczesna. Zwłaszcza że tożsamość ta właśnie zmienia się na naszych oczach.

${ }^{40}$ M. de Certeau, Wynaleźć codzienność. Sztuki dziatania, tłum. K. Thiel-Jańczuk, Kraków 2008, s. 98. 


\section{Bibliografia}

Barthes R., Roland Barthes, tłum. T. Swoboda, Gdańsk 2011.

Charon R. i in., Medycyna narracyjna, tłum. M. Świątkowska, red. M.K. Potoniec, H. Syzdek, Kraków 2021.

Certeau M. de, Wynaleźć codzienność. Sztuki dziatania, tłum. K. Thiel-Jańczuk, Kraków 2008.

Filipkowski P., Historia mówiona i wojna. Doświadczenie obozu koncentracyjnego w perspektywie narracji biograficznych, Wrocław 2010.

Ginzburg C., Tropy. Korzenie paradygmatu poszlakowego, tłum. Tadeusz Sierotowicz, „Zagadnienia Filozoficzne w Nauce” 2006, XXXIX.

Godlewski G., Luneta $i$ radar. Szkice z antropologicznej teorii kultury, Warszawa 2016.

Goody J., Logika pisma a organizacja spoteczeństwa, tłum., wstęp i red. G. Godlewski, Warszawa 2006.

Ingold T., Rysowanie, pisanie i kaligrafia, tłum. M. Rakoczy, „Teksty Drugie” 2015, nr 4.

Lejeune Ph., Autobiografia $w$ trzeciej osobie, tłum. S. Jaworski [w:] tegoż, Wariacje na temat pewnego paktu. O autobiografii, tłum. W. Grajewski i in., red. R. Lubas-Bartoszyńska, Kraków 2001.

Leroi-Gourhan A., Gesture and Speech, wstęp R. White, tłum. A. Bostock Berger, Cambridge-London 1993.

MacIntyre A., Dziedzictwo cnoty. Studium z teorii moralności, tłum., wstęp i przypisy A. Chmielewski, tłum. przejrzał J. Hołówka, Warszawa 1996.

Majewski P., Tekstualizacja doświadczenia. Studia o piśmiennictwie greckim, Warszawa-Toruń 2015.

Medycyna narracyjna. Opowieści o doświadczeniu choroby w perspektywie medycznej i humanistycznej, red. M. Chojnacka-Kuraś, Warszawa 2019.

Narracja jako sposób rozumienia świata, red. J. Trzebiński, Gdańsk 2002.

Narrative Sociology, red. L.J. Irvine, J.L. Pierce, R. Zussman, Nashville 2019.

Parker D., Narracja autobiograficzna i języki dobra, tłum. A. Skucińska, „Konteksty Kultury" 2021, t. 18, z. 1.

Rakoczy M., Materia, ciato, wizualność, czyli jak zrozumieć pisanie, „Teksty Drugie" 2015, nr 4.

Rakowski T., Łowcy, zbieracze, praktycy niemocy. Etnografia cztowieka zdegradowanego, Gdańsk 2009.

Ricour P., Czas i opowieść, t. 3: Czas opowiadany, tłum. U. Zbrzeźniak, Kraków 2008.

Ricœur P., O sobie samym jako innym, tłum. B. Chełstowski, oprac. i wstęp M. Kowalska, Warszawa 2005.

Rosner K., Narracja, tożsamość i czas, Kraków 2003.

Strawson Galen, Against Narrativity, „Ratio (new series)” 2004, nr 4 (XVII).

Taylor Ch., The Language Animal: The Full Shape of the Human Linguistic Capacity, Cambridge-London 2016. 
Taylor Ch., Źródta podmiotowości. Narodziny tożsamości nowoczesnej, tłum. M. Gruszczyński i in., oprac. T. Gadacz, wstęp A. Bielik-Robson, Warszawa 2001.

Tischner Ł., Perspektywa etyczna w badaniach nad literatura i religia. Redukcja czy konieczne dopetnienie? [w:] Literatura a religia - wyzwania epoki świeckiej, t. 1: Teorie i metody, red. Ł. Tischner, T. Garbol, Kraków 2020. 